\title{
Work-nonwork conflict: an urgent situation for Brazilian women
}

\author{
Érica Custódia de Oliveira and Tania Casado \\ Faculdade de Economia, Administração e Contabilidade, \\ Universidade de São Paulo, Sao Paulo, Brazil
}

\begin{abstract}
Purpose - Going further on a broad understanding of nonwork besides family, this study aims to analyze differences between women and men considering work-nonwork conflict (WNWC) in the Brazilian context, investigating time spent in eight nonwork dimensions and the dimensions more affected.

Design/methodology/approach - The study was quantitative and descriptive. A survey was conducted, based on a validated WNWC scale. The sample consisted of 338 professionals working in Brazil. Data analysis was conducted through descriptive statistics and analysis of variance.

Findings - Compared to men, women declare higher levels of WNWC considering the eight nonwork dimensions, present greater differences in stress-based conflicts and in more collective dimensions and have marriage or no children associated with more WNWC.

Research limitations/implications - The study highlights the need to include more nonwork aspects into career and management studies to influence organizational practices and individual choices. The main limitation is the non-probabilistic sample (results not generalizable).

Practical implications - Know more about WNWC will help organizations to improve lives by creating practices and a cultural environment to preserve women's and men's nonwork times. It may also help people to choose places to work for, matching their nonwork needs.

Social implications - The study reinforces demands from new family arrangements, more couples in dual-career and an aging society: organizations must prepare to have workers that want or need to dedicate time to other interests besides family or children.

Originality/value - It goes further on a broad understanding of nonwork besides family to understand WNWC and how it may affect differently men and women.
\end{abstract}

Keywords Women, Men, Work-nonwork conflict

Paper type Research paper

\section{Introduction}

Social changes such as the increasing presence of women in the labor market [IBGE Instituto Brasileiro de Geografia e Estatística, 2000, 2010], couples in dual-career and new family arrangements (IBGE - Instituto Brasileiro de Geografia e Estatística, 2013a, 2013b), have made the so-called ideal worker much rarer, i.e. a worker who could simply focus his responsibilities and priorities on work and count on someone else to organize life besides work (Bailyn, 2006). Work is defined as activities the individual carries out to make a living. The boundary between work and nonwork causes not only professional impacts: conflict

(C) Érica Custódia de Oliveira and Tania Casado. Published in RAUSP Management Journal. Published by Emerald Publishing Limited. This article is published under the Creative Commons Attribution (CC BY 4.0) licence. Anyone may reproduce, distribute, translate and create derivative works of this article (for both commercial and non-commercial purposes), subject to full attribution to the original publication and authors. The full terms of this licence maybe seen at http:// creativecommons.org/licences/by/4.0/legalcode 
RAUSP

56,1

from work invading nonwork is a relevant dilemma because it affects physical and mental health (Grzywacz \& Butler, 2008); and it is a social problem, as there is pressure for everyone (Bailyn, 2006). There is a conflict when work consumes too much time, generates too much stress or makes it harder for the individual to dedicate himself to other life domains (Keeney, Boyd, Sinha, Westring, \& Ryan, 2013).

Despite the few recent studies showing that people want to dedicate themselves to different nonwork dimensions (Keeney et al., 2013; Oliveira \& Casado, 2013), management studies on work and nonwork relationships have been focusing on family since the 1980s (Greenhaus \& Beutell, 1985; Eby, Casper, Lockwood, Bordeaux, \& Brinley, 2005). Then, many of these studies have already found a negative relationship between work-family conflict and workers' well-being, satisfaction with work, family and life (Bedeian, Burke, \& Moffett, 1988; Rice, Frone, \& McFarlin, 1992; Kossek \& Ozeki, 1998; Carlson \& Perrewé, 1999; Anderson, Coffey, \& Byerly, 2002; Lapierre \& Allen, 2012; Oliveira, Cavazotte, \& Paciello, 2013) or between the work-nonwork conflict (WNWC) and the same satisfaction with work, family and life (Keeney et al., 2013).

Emphasizing family as nonwork, however, may underestimate gender differences and lead to misunderstandings (Byron, 2005), as studies reveal that women possibly accept family care as their task (Rocha-coutinho, 2004; Bailyn, 2006; Chies, 2010; Madalozzo, Martins, \& Shiratori, 2010). As a result, women would often report less work-family conflict but, at the same time, they would find no place to express themselves about the other nonwork dimensions invaded (Eby et al., 2005; Keeney et al., 2013). What if work has made it much more difficult to dedicate time to health, friendships, education or leisure, for example?

This context highlights the need to expand academic concerns with understanding which of the nonwork dimensions, besides family, conflict from work affects more and if there are differences between women and men: those are the academic contributions proposed in this study. This understanding is an important step to subside managers into implementing practices for improving workers' and society's well-being: to be more productive at work and feel better, people need to have time and energy to dedicate themselves to other life dimensions too and organizations need to have policies and practices that create cultural (respect for individual needs besides work) and managerial support for this purpose. This understanding also contributes to subside people into thinking about their nonwork time and choosing a social environment to work in that matches their nonwork needs. To prevent and combat conflict between work and nonwork is an important step because productivity and career and life satisfaction levels are higher when people can dedicate themselves to different life dimensions (Marks, 1977; Bailyn, 2006; Hirschi, Herrmann, Nagy, \& Spurk, 2016).

Targeting this need and due to the lack of studies about the WNWC in Brazil, the problem question presented is "Does gender influence the work-nonwork conflict (WNWC)?" To answer this question, the article's objective is to analyze differences between women and men considering WNWC in the Brazilian context, investigating the time spent in the nonwork dimensions and the dimensions that are more affected in this conflict.

\section{Theoretical background}

Studies on the relation between work and nonwork have considered nonwork as a synonym of the family at least since 1985, when Greenhaus and Beutell theorized, based on Goode's (1960) vision of natural stress occurring while people fulfill different social roles and from Kahn, Wolfe, Quinn, Snoek and Rosenthal's vision (1964, p. 19) of role conflict as the 
"[...] simultaneous occurrence of two (or more) sets of pressures such that compliance with one would make more difficult compliance with the other."

Studies that expand nonwork besides the family are more recent and still rare (OlsonBuchanan \& Boswell, 2006; Kreiner, 2006; Kreiner, Hollensbe, \& Sheep, 2009; Oliveira \& Casado, 2013; Haar, 2013; Keeney et al., 2013). That is why the first theoretical section (2.1) presents how WNWC has been studied as an evolution from work-family conflict and the second section (2.2) discusses what has been researched about how women and men perceive this conflict.

\subsection{Work-nonwork conflict}

WNWC is defined as "[...] difficulty participating in nonwork domains by virtue of participation in the work domain." (Keeney et al., 2013, p. 221). This construct is an expansion from work-family conflict (WFC) (Greenhaus \& Beutell, 1985), as they have the same conceptual basis of role conflict (Kahn et al., 1964), but WNWC includes other nonwork roles besides the family role.

The first studies investigating WNWC (Olson-Buchanan \& Boswell, 2006; Kreiner, 2006; Kreiner et al., 2009) used terms such as life and home as if they were synonymous with family and personal life indiscriminately. In this article, the option for the term worknonwork instead of work-life follows Bailyn's proposal (2006), which defends work as one of the various dimensions of life and, consequently, inseparable from life itself. Earlier, Thompson and Bunderson (2001, p. 18) had investigated nonwork as family, friends and leisure but, approaching "[. . . time as a container of meaning": they affirm that the more the activities affirm an individual's identity, the less the tendency for him/her to perceive conflict, but admit that time is finite and that, if work demands too much of it, there may be conflict anyway.

Keeney et al.'s (2013) conceptual proposal for WNWC was chosen for this article because it highlights that individuals may have diverse nonwork interests. After searching for dimensions related to life satisfaction, stress, self-identity or personal goals, the authors (2013) proposed eight nonwork dimensions in their model: health, family, household management, friendships, education, romantic relationships, community involvement and leisure. Validating the WNWC scale that considered those eight nonwork dimensions, they "[...] identified a useful starting point for future research with a broad and, as the results suggest, a sufficiently distinct set of life domains for investigation." (Keeney et al., 2013, p. 233). They also replicated the WFC dominant measurement framework, whose main sources are time and stress (Greenhaus \& Beutell, 1985). The final model (Figure 1) represents the WNWC multidimensional construct (16 factors: 8 nonwork dimensions X 2 sources), also validated for a Brazilian sample (Oliveira \& Casado, 2017).

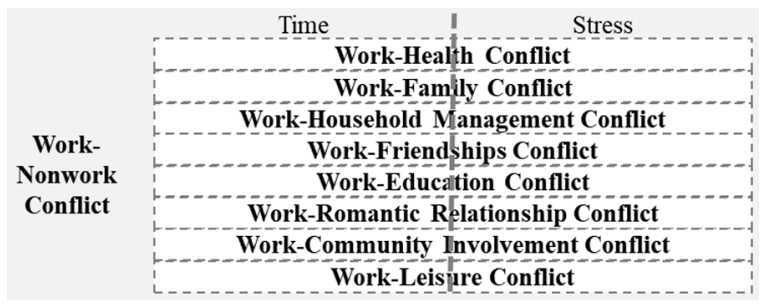

Source: Elaborated by authors, based on Keeney et al. (2013)

\section{Urgent situation for Brazilian women}

73 
RAUSP

56,1

Previous to Keeney et al.'s (2013) proposal for WNWC, some studies were investigating this conflict under the Border Theory lens: boundaries between work and nonwork can be stronger or weaker (Nippert-Eng, 1996) and people would diminish conflict by finding workplaces where their preferences for more segmentation (stronger borders) or integration (weaker borders) between work and nonwork could be achieved (Rothbard, Phillips, \& Dumas, 2005; Chen, Powell, \& Greenhaus, 2009).

So, while Olson-Buchanan and Boswell (2006) investigated work-nonwork integration and discovered conflict when work was more integrated toward nonwork, Kreiner (2006) found lower stress levels for people with no preference between segmentation and integration. Using a qualitative approach, Kreiner et al. (2009) focused on tactics chosen by people for managing boundaries and achieving the desired level of segmentation-integration between work and home, reducing the conflict.

The Brazilian study (Oliveira \& Casado, 2013) is also previous to Keeney et al.'s (2013) model and considered nonwork as a family and personal life. The respondents reported a desire to allocate time from the professional dimension into the two other dimensions, mainly the personal one - this can be understood as time-based conflict. These results were stronger for women, no matter if they had children or not.

When Keeney et al. (2013) validated the WNWC model, they considered participation in each of the nonwork dimensions as estimators of these dimensions' salience for respondents people would participate in dimensions that are important to them. In this study, more people participate in household management, leisure, health and friendships dimensions $(96 \%$ to $99 \%$ of respondents) than in the family dimension (91\%), reinforcing the need to expand and differ nonwork dimensions besides family. Considering WNWC, the more affected dimensions were time and stress-based health and leisure and time-based family.

\subsection{Work-nonwork conflict and differences between women and men}

As highlighted, nonwork has just recently been studied besides the family dimension, which is the reason why this chapter will continue to explore mainly investigations about sex or gender and work-family conflict (not WNWC). This study used the more traditional view of sex as a biological characteristic that identifies a person as male or female and gender as a characteristic constructed by socialization (Calás \& Smircich, 2007), despite other perspectives such as Butler's (2016), in which both sex and gender are discursively constructed, before culture, that is, neutral surfaces which culture acts on.

In management investigations on WNWC, the authors seem to use the terms sex and gender indiscriminately, as they ask respondents about being a man or a woman to define gender, but without a further discussion about it. This indicates the focus on men and women without deepening what distinguishes them or which other sexes or genders might exist.

There is an idea that managing work-family interface is more challenging for women than for men (Shockley et al., 2017), which was investigated in the two meta-analyzes presented next.

In the first meta-analysis (190 studies), Eby et al. (2005) found diverse empirical results: some of them pointed to more work-family conflict for women, while others pointed to the opposite. The authors explain this result by women's other nonwork interests besides family: women would still understand family care as their task and not their partners' and feel more conflict toward other nonwork dimensions, but without a way to express it. Considering the findings of this meta-analysis and the validated WNWC multidimensional construct (Keeney et al., 2013; Oliveira \& Casado, 2017), the first hypothesis proposed is:

H1. For women, other nonwork dimensions than family are more affected in the WNWC. 
In the second meta-analysis (350 empirical samples), Shockley et al. (2017) found partial support for two theoretical perspectives: the rational view (hours worked associated with workfamily) and the asymmetrical domain permeability (less work-family conflict for women) - and no support for the gender role-expectations and the male segmentation perspective (more workfamily conflict for women). Table 1 explains these four theoretical perspectives.

Shockley et al. (2017, p. 13) also recommended exploring "[ . . . the role of gender-specific expectations and socialization," a perspective explained by the sexual division of labor: it points out that men are socially expected to be responsible for productive work outside the home, while women are expected to attend to the reproductive, domestic and family work (Hirata \& Kergoat, 2003). By doing so, men fulfill both work and family demands, supporting the family financially, while women fulfill the mother and spouse roles. Consequently, work and family demands are mutually supportive for men, but competitive for women, possibly causing internal conflict and guilt for women who occupy dual roles (Hirata \& Kergoat, 2003; Borelli, Nelson, River, Birken, \& Moss-Racusin, 2017). These feelings would explain women forming strong boundaries around family (the asymmetrical domain permeability model (Ashforth et al., 2000)) as a coping strategy for managing work and family, as women see maternity as the essence of being a woman (Rocha-coutinho, 2004).

The sexual division of labor reinforces gender roles and that men's productive work is worth more than women's reproductive work. It appears in the organizational world in objective and subjective parameters: respectively, women gain a lower wage than men even when they do the same job and women face invisible barriers to grow hierarchically, described in metaphors such as glass ceiling (barriers to achieving the highest hierarchical positions; Hymowitz \& Schelhardt, 1986) or labyrinth (there are complex and subtle challenges, but persistence, careful analysis of the puzzles ahead and hard work can lead to professional growth; Eagly \& Carli, 2007). In Brazil, women gain just $77.5 \%$ of men's wages (IBGE - Instituto Brasileiro de Geografia e Estatística, 2018) and occupy only $12 \%$ of senior management positions (Instituto Ethos, 2018).

About conflict from work, organizations also reinforce maternity, but not paternity, as a possible cause when they direct policies to address family concerns only to women (Hirata \& Kergoat, 2003), keeping a structure that rewards men who can work long hours (Goldin, 2013). The same thing happens when the law grants different maternity and paternity leaves: in Brazil, for example, they are of 120 and 5 days, respectively, (2018).

\begin{tabular}{ll}
\hline Theory & Explanation \\
\hline Rational view (Gutek, Searle, \& Klepa, 1991) & $\begin{array}{l}\text { Time spent on work and family domains affects how much } \\
\text { conflict a person experiences - hours worked are associated } \\
\text { with work-family conflict, no matter the gender }\end{array}$ \\
$\begin{array}{ll}\text { Asymmetrical domain permeability (Pleck, } \\
\text { Women and men form asymmetrical boundaries around } \\
\text { work and family, with women constructing stronger } \\
\text { boundaries around family and men around work }\end{array}$ \\
$\begin{array}{ll}\text { - Men value work more than women due to social pressure } \\
\text { (family obligations are women's tasks and professional }\end{array}$ \\
et al., 2017) & $\begin{array}{l}\text { obligations men's tasks), resulting in men being more } \\
\text { sensitive to intrusions into work and women to intrusions } \\
\text { into family }\end{array}$ \\
$\begin{array}{l}\text { - Men have more impermeable family and work roles than } \\
\text { women }\end{array}$
\end{tabular}

Source: Elaborated by authors

\section{Urgent situation for Brazilian women}

75 
RAUSP

56,1

Concerning work beside and at home, Brazilian women work $7.5 \mathrm{~h}$ more per week than men: women work $53.6 \mathrm{~h}$ weekly - 18.7 at home and 34.9 outside - and men $46.1 \mathrm{~h}$ weekly -5.3 at home and 40.8 outside (IBGE - Instituto Brasileiro de Geografia e Estatística, 2015a, 2015b). However, as women work fewer hours than men outside of the home, considering the rational view theory, the second hypothesis can be proposed:

H2. Women perceive less work-family conflict than men.

Two qualitative studies on Brazilian professional women found to conflict, even though it did not figure among the main research issues. The first study (Morgado, 2012) involved 42 respondents and 38 of them brought up the issue spontaneously, indicating that having small kids played a determinant role in the conflict. Women with children showed anguish for having to divide themselves among different activities, while women without children talked about anguish due to too much dedication to work, to not establishing limits to professional life. So, with or without children, women feel anguished.

In the second study, focused on how human resources professionals understand their actions regarding organizational justice related to gender, Lucas (2015) found conciliation between career and maternity as a conflict. No question was asked about the respondents' personal lives. Nevertheless, the interviewed women talked about their difficulties in being workers and mothers, while men talked about paternity, but without relating it to conflict. This difficulty to conciliate maternity and career has already been highlighted as one of the reasons why executive women started abandoning their careers in the USA, giving rise to the opt-out revolution (Belkien, 2003).

These spontaneous occurrences indicate that conflict is an important subject for women, especially for mothers, probably also resulting from contradictory expectations attributed to women when they decide to have children: they should manage work-family conflict, bear long workdays and participate in events beyond working hours (Metz, 2011; Cahusac \& Kanji, 2014). Considering such work environment requirements, it is plausible that only $48 \%$ of Brazilian women with children would choose to work if they had the option not to, versus $74 \%$ of Brazilian women without children (Venturi \& Godinho, 2013 as cited by Lucas, 2015). Those data originate the third hypothesis, focusing one more time on the family dimension, which was strongly and spontaneously associated with conflict in those studies discussing women's careers:

H3. Women with children perceive more work-family conflict than women without children.

\section{Methods}

This quantitative and descriptive research is based on Keeney et al.'s WNWC model (2013). The main variable, WNWC, is conceptually defined as the difficulty in participating in nonwork dimensions due to the time spent at work or stress generated by work (Kahn et al., 1964; Greenhaus \& Beutell, 1985; Keeney et al., 2013). This variable is also operationally defined using Keeney et al.'s scale (2013) [1] [2], which was translated into Portuguese, evaluated by three experts in the area and back-translated into English by a specialized professional. A pre-test before the start of the data collection showed that no extra adjustments were needed.

The universe consists of people with a higher education degree who work in Brazil, estimated at 7.75 million individuals [3]. The sample of 338 respondents (professionals working in Brazil) was non-probabilistic, intentional and convenience-based. The invitation 
to participate in this research was sent by email messages, mainly to the mailing of a highranked business school in Brazil [4].

Data were collected using an electronic self-reporting questionnaire, detailed in Table 2, elaborated to make self-reporting easier, aiming for adaptation to the context, ability to capture the variables of interest, reliability and validity (Sampieri, Collado, \& Lucio, 2006). To avoid missing values, the questions were programmed to have a mandatory response on the data collection platform. It was also possible to randomize the 48 WNWC items, so the order in which they appeared in each of the 16 questions varied among the respondents.

Descriptive analysis and analysis of variance were done using SPSS 20. The descriptive analysis was used to characterize the sample and estimate the men's and women's time allocation to the eight nonwork dimensions and the intensity of the 16 WNWC factors (Figure 1).

Analysis of variance ( $t$-test for two groups and ANOVA for more than two groups) was used to evaluate statistical differences in time allocation in eight nonwork dimensions and differences in the intensity of 16 WNWC factors between women and men (and among subgroups), as this technique is used when the dependent variables are metric and the independent ones nonmetric. The next section highlights the statistically significant results $(p<0.05)$.

The assumptions of analysis of variance were checked - independence of observations, a minimal sample of 20 elements for each group, absence of outliers, homoscedasticity and normality of variables (Tabachnick \& Fidell, 2007; Hair, Black, Babin, Anderson, \& Tatham, 2009). All assumptions were fulfilled accept the normality of variables; nevertheless, this causes a low impact on results, as this is a big sample study (Hair et al., 2009).

Following Sweeney, Williams, and Anderson (2013), the paired $t$-test was used for comparing averages of two measures coming from the same elements (within-subjects technique): in this article, to evaluate statistical differences in the intensity of the 16 WNWC factors among men and among women.

\begin{tabular}{|c|c|c|c|}
\hline Block & Research variable & Operational definition & No. of items \\
\hline 1 & 2 variables to filter & $\begin{array}{l}\text { - If the respondent worked in Brazil at the moment } \\
\text { - Education level (with options) }\end{array}$ & 2 \\
\hline 2 & $\begin{array}{l}8 \text { variables about time } \\
\text { allocation to nonwork } \\
\text { dimensions }\end{array}$ & Likert scale from $1=$ no time to $7=$ a lot of time & $\begin{array}{l}8 \text { (1 per } \\
\text { variable) }\end{array}$ \\
\hline 3 & $\begin{array}{l}16 \text { variables referring to the } \\
\text { work-nonwork conflict }\end{array}$ & $\begin{array}{l}\text { Scale translated from Keeney et al. (2013), Likert } \\
\text { from } 1=\text { totally disagree to } 7=\text { totally agree }\end{array}$ & $\begin{array}{l}48 \text { ( } 3 \text { per } \\
\text { variable) }\end{array}$ \\
\hline 4 & Demographic variables & $\begin{array}{l}\text { - Length of professional experience (in years) } \\
\text { - Residence city and state } \\
\text { - Age (in years) } \\
\text { - Sex/gender (female or male) } \\
\text { - Marital status (with options) } \\
\text { - Number of children under } 18 \text { years-old } \\
\text { - Main professional occupation or position (with } \\
\text { options) } \\
\text { - Work hours per week } \\
\text { - If studying or not at that moment }\end{array}$ & 9 \\
\hline
\end{tabular}

Source: Elaborated by authors

\section{Urgent situation for Brazilian women}


RAUSP

56,1

78

\section{Results and discussion}

\subsection{Characteristics of the sample}

The sample includes $50.3 \%$ men and $49.7 \%$ women, with an average age of 35 years old (standard deviation $(\mathrm{SD})=8.5$ ), concentrated in the Brazilian Southeast $(93.2 \%)$ and mostly married $(60.9 \%)$. Most respondents have no children $(68.3 \%), 18.9 \%$ have one child and $10.9 \%$ have two children. As the focus is on investigating the whole WNWC (its 16 factors) and not just the work-family conflict, it is interesting to have a sample mostly without children because they represent the social changes mentioned (IBGE - Instituto Brasileiro de Geografia e Estatística, 2000, 2010, 2013a, 2013b), which reinforce the need to investigate nonwork besides the family dimension.

Concerning the respondents' professional occupation, they are mostly specialists $(37.0 \%)$, managers $(23.1 \%)$ or supervisors/coordinators $(18.3 \%)$. They work $46.6 \mathrm{~h}$ per week on average, with no statistical difference between men ( $46.8 \mathrm{~h}$ ) and women ( $46.3 \mathrm{~h})$.

As the participants were mainly accessed through the mailing list of a business school in São Paulo (82.8\% respondents), it is expected that most of them studied when the data were collected (68.6\%); considering these respondents, $83.6 \%$ were taking a lato sensu postgraduation course.

Regarding their individual income, the average is US\$2,692.2 with high dispersion and a greater concentration in the ranges between US\$1,013.0 and US\$2,026.0 (31.1\%) and between US $\$ 2,026.0$ and US\$3,039.0 (25.4\%). Close to general Brazilian data (IBGE Instituto Brasileiro de Geografia e Estatística, 2018; Instituto Ethos, 2018), female respondents have income $20 \%$ lower than men and occupy fewer senior management positions ( $1.2 \%$ of women are President or Director versus $6.5 \%$ of men), even with a higher proportion of women in the sample holding a post-graduation degree $59.5 \%$ of women versus $55.9 \%$ of men), the same average age between sexes (35 years) and fewer women with children ( $25 \%$ of women versus $38.2 \%$ of men).

\subsection{Time allocation to eight nonwork dimensions}

Analyzing time allocation by men and by women, there is no statistical difference $(\phi<0.05)$, as shown in Table 3. That means they express similar perceptions about the time allocated to nonwork dimensions, indicating that men and women attribute similar degrees of importance (salience) to each dimension (Keeney et al., 2013).

The respondents reported spending time mostly on education (4.89), family (4.86) and romantic relationships (4.59). Time allocated to education could be biased because respondents

Table 3.

Time allocation to different nonwork dimensions: highlighting women and men

\begin{tabular}{|c|c|c|c|c|c|}
\hline \multirow[b]{2}{*}{ Nonwork dimensions } & \multicolumn{3}{|c|}{ Mean } & \multicolumn{2}{|c|}{ Coefficient of variation (CV) } \\
\hline & All sample & Women & Men & Women $(\%)$ & $\operatorname{Men}(\%)$ \\
\hline Education & 4.89 & 4.98 & 4.81 & 26 & 28 \\
\hline Family & 4.86 & 4.93 & 4.79 & 25 & 29 \\
\hline Romantic relationships & 4.59 & 4.45 & 4.74 & 36 & 30 \\
\hline Leisure & 4.36 & 4.32 & 4.41 & 30 & 28 \\
\hline Friendships & 4.19 & 4.24 & 4.14 & 33 & 34 \\
\hline Household management & 4.14 & 4.28 & 4.01 & 35 & 36 \\
\hline Health & 3.89 & 3.95 & 3.84 & 37 & 38 \\
\hline Community involvement & 2.35 & 2.38 & 2.31 & 61 & 60 \\
\hline Number of respondents & 338 & 168 & 170 & 168 & 170 \\
\hline
\end{tabular}

Source: Elaborated by the authors, based on the research data 
were contacted through the mailing list of a business school, but there was no significant influence from the variable "studying at the moment or not" on the main construct, WNWC - this variable did not generate a significant difference in the reported conflict intensities.

Variation (Table 3, coefficient of variation) among the respondents was also found concerning the time spent in each nonwork dimension, reflecting different priorities. This variety is an important finding, related to Keeney et al.'s (2013) defense of using diverse nonwork dimensions while investigating WNWC: people spend time in different nonwork dimensions and in different ways, so they may find work invading those dimensions too, not the only family.

When the variables sex and marital status are joined, differences come up in the time allocated to household management: married women (4.63) and men (4.30) allocate more time to this dimension when compared to single people (3.63 and 3.31). Similar results appear when sex and "having children or not" are considered simultaneously: women with children allocate more time to household management (4.93) than people without children (4.06 and 3.84). So, while marriage seems to impact women and men considering the time allocated to household management, children generate a greater impact for women, even in a sample with an individual average income of US\$2,692.2 per month, 10 times higher than the Brazilian minimum wage. Those results are in line with data presented by IBGE Instituto Brasileiro de Geografia e Estatística (2015a, 2015b) and the sexual division of labor (Hirata \& Kergoat, 2003): Brazilian women work more than three times longer at home when compared to men (18.7 versus $5.3 \mathrm{~h}$ weekly), indicating domestic and family work concentrated in women.

\subsection{Work-nonwork dimensions affected in work-nonwork conflict: differences between women and men}

Different paired groups were compared (for example, women and men, married people and single ones) to investigate which characteristics influenced WNWC and sex was the only characteristic generating a statistical difference between groups $(\phi<0.05)$.

All 16 WNWC factors are higher for women than for men (Table 4), results similar to Oliveira and Casado (2013) and Keeney et al. (2013). As the work-family conflict is one of the

\begin{tabular}{lrrrrrr}
\hline \multicolumn{3}{c}{} & \multicolumn{3}{c}{ Mean } \\
Nonwork dimensions affected & Women & $\begin{array}{c}\text { Time-based } \\
\text { Men }\end{array}$ & Difference & Women & $\begin{array}{c}\text { Stress-based } \\
\text { Men }\end{array}$ & Difference \\
\hline Household management & 4.99 & 4.14 & 0.85 & 5.13 & 4.30 & 0.83 \\
Health & 4.90 & 4.26 & 0.64 & 5.05 & 4.34 & 0.71 \\
Education & 4.97 & 4.34 & 0.63 & 5.00 & 4.30 & 0.71 \\
Leisure & 4.98 & 4.50 & 0.48 & 4.73 & 3.95 & 0.79 \\
Friendships & 4.90 & 4.30 & 0.60 & 4.68 & 3.84 & 0.85 \\
Family & 4.84 & 4.21 & 0.63 & 4.63 & 3.77 & 0.86 \\
Community involvement & 4.65 & 3.86 & 0.80 & 4.67 & 3.66 & 1.01 \\
Romantic relationships & 4.31 & 3.75 & 0.56 & 4.45 & 3.73 & 0.72 \\
Number of respondents & 168 & 170 & - & 168 & 170 & -
\end{tabular}

Notes: In this table, results are shown in descending order for women as their conflict intensity is always higher. The data highlighted in italic presented statistically significant differences (t-test) at $p<0.05$ Source: Elaborated by the authors, based on the research data

\section{Urgent situation for Brazilian women}


RAUSP

56,1
16 factors, this specific result leads to the rejection of $H 2$. This result connects to the idea that work and family demands are competitive for women, generating internal conflict when women occupy dual roles (Hirata \& Kergoat, 2003; Borelli et al., 2017). Different from Shockley et al.'s (2017), it supports the gender role-expectations theory: maybe women are more sensitive to intrusions into the family role, subjectively experiencing more work-family conflict.

Even though women and men declare allocating similar time to nonwork dimensions (Table 3 ) and to work beyond the home (46.3 and 46.8, respectively), women perceive higher WNWC (18\% higher on average) compared to men: it seems harder for women to save time or energy from work to the eight nonwork dimensions, even when going out to work the same number of hours than men. This result is different from Shockley et al.'s (2017) because it does not match the rational view theory: worked hours presented a merely low correlation with 11 of the 16 WNWC factors.

Analyzing each of the 16 WNWC factors (Table 4), considering that the paired $t$-test showed $|0,15|$ as the limit for a statistical difference in this data set, there are, for women, three dimensions that are more affected than family (time-based: 4.84): household management (stress-based: 5.13; time-based: 4.99), health (stress-based: 5.05) and education (stress-based: 5.00). This result leads to support for $H 1$

This result matches Keeney et al.'s (2013) - the work-family conflict was not the highest for women either - and reinforces the use of other nonwork dimensions while investigating conflict from work, helping to explain inconsistencies when the sexes are compared (Byron, 2005; Eby et al., 2005): women still understand family care as their own and not their partners' task (Rocha-coutinho, 2004) and feel guilty by admitting not to protect this dimension enough (the gender role-expectations theory), but they declare higher levels of conflict toward other nonwork dimensions when given the opportunity. Furthermore, Brazilian results are similar to results found in North America: women perceive higher general WNWC - in Keeney et al.'s study (2013), 14 out of 16 WNWC factors were higher for women.

An interesting aspect of the data is that, for men, the most intense conflicts (time-based work-leisure, 4.50 and stress-based work-health, 4.34) are perceived with a similar intensity level as the lowest conflicts for women (time-based (4.31) and stress-based (4.45) workromantic relationships). So, not just women perceive more conflict than men (all 16 WNWC factors) but, also, women's lowest conflict levels are like men's highest ones. So, maybe not just work and family roles are competitive for women (Hirata \& Kergoat, 2003; Borelli et al., 2017), but the same occurs with work and the other nonwork roles. One possible explanation is that the researched Brazilian women try to face the invisible barriers to growing hierarchically - glass ceiling (Hymowitz \& Schelhardt, 1986) and labyrinth (Eagly \& Carli, 2007) - by dedicating themselves to work much more than they wanted. Then, yet those researched women gain an income $20 \%$ lower than the researched men (US $\$ 2,390.0$ versus US $\$ 2,983.9)$ and occupy fewer senior management positions $(1.2 \%$ of the women are President or Director versus $6.5 \%$ of men), even though more women than men hold a post-graduation degree (59.5\% of women versus $55.9 \%$ of men) and fewer women have children ( $25 \%$ of women versus $38.2 \%$ of men), at the same average age as men (35 years).

Still comparing both sexes (Table 4, columns Difference), greater differences appear for women considering stress-based conflicts ( 0.81 on average) than time-based conflicts ( 0.65 on average). Then, the biggest differences are in dimensions that involve other people: community involvement (1.01), family (0.86), friendships (0.85) and household management (0.83). These findings suggest social pressure intensifying 
women's conflict perception in collectively experienced dimensions when compared to more individual dimensions such as health and education. Once again, this may come from the sexual division of labor (Hirata \& Kergoat, 2003): the expectation that women take care of the family expands to other relationships, like community-based or friendship bonds; there would be more guilt because it concerns other people (Hirata \& Kergoat, 2003; Borelli et al., 2017).

As happened with time allocation to the eight nonwork dimensions (Table 3), variation also occurred among the respondents considering conflict: for the 16 WNWC factors, the coefficient of variation varied from $33 \%$ to $44 \%$, reinforcing the need for human resources practices (for saving nonwork time) coherent to this diversity and not only concentrated on family questions.

4.3.1 Differences combining sex, marital status and/or "having children or not." Combining the variables sex and marital status (Table 5), the group of married women stands out: for them, 14 WNWC factors are higher compared to married men, indicating marriage as a direct influence on conflict perception for both sexes. The greater conflicts include work-family and work-household management, indicating that wives are still responsible for most of the household and family care, which resembles Morgado's (2012) results. Again, this seems explainable by the sexual division of labor (Hirata \& Kergoat, 2003), apparently highlighted in married couples.

When the variables sex and "having children or not" are considered simultaneously (Table 5), the group of women without children stands out: for them, 11 WNWC factors are higher, mostly compared to men with or without children. So, as there is no statistical

\begin{tabular}{|c|c|c|c|c|c|c|c|c|}
\hline \multirow[b]{4}{*}{$\begin{array}{l}\text { Nonwork dimensions } \\
\text { affected }\end{array}$} & \multicolumn{8}{|c|}{ Mean } \\
\hline & \multicolumn{4}{|c|}{ Sex and marital status } & \multicolumn{4}{|c|}{ Sex and "having children or not" } \\
\hline & \multicolumn{2}{|c|}{ Women } & \multicolumn{2}{|c|}{ Men } & \multicolumn{2}{|c|}{ Women } & \multicolumn{2}{|c|}{ Men } \\
\hline & Single & Married & Single & Married & $\begin{array}{l}\text { Without } \\
\text { children }\end{array}$ & $\begin{array}{c}\text { With } \\
\text { children }\end{array}$ & $\begin{array}{l}\text { Without } \\
\text { children }\end{array}$ & $\begin{array}{c}\text { With } \\
\text { children }\end{array}$ \\
\hline \multicolumn{9}{|l|}{ Time-based conflicts: } \\
\hline Household management & 5.12 & 4.93 & 4.39 & 4.04 & 5.07 & 4.77 & 4.18 & 4.07 \\
\hline Health & 4.73 & 4.99 & 4.61 & 4.12 & 5.01 & 4.58 & 4.43 & 3.98 \\
\hline Education & 5.10 & 4.90 & 4.97 & 4.09 & 5.09 & 4.60 & 4.43 & 4.19 \\
\hline Leisure & 4.86 & 5.04 & 4.82 & 4.37 & 5.03 & 4.83 & 4.62 & 4.31 \\
\hline Friendships & 4.98 & 4.87 & 4.59 & 4.18 & 5.03 & 4.53 & 4.31 & 4.28 \\
\hline Family & 4.66 & 4.94 & 4.33 & 4.15 & 4.82 & 4.90 & 4.24 & 4.15 \\
\hline Community involvement & 4.51 & 4.73 & 4.00 & 3.80 & 4.66 & 4.63 & 3.78 & 3.97 \\
\hline Romantic relationships & 4.39 & 4.27 & 4.14 & 3.58 & 4.34 & 4.21 & 3.76 & 3.72 \\
\hline \multicolumn{9}{|l|}{ Stress-based conflicts: } \\
\hline Household management & 5.11 & 5.14 & 4.59 & 4.18 & 5.20 & 4.90 & 4.33 & 4.25 \\
\hline Health & 4.76 & 5.21 & 4.66 & 4.21 & 5.12 & 4.84 & 4.48 & 4.11 \\
\hline Education & 5.05 & 4.98 & 5.01 & 4.01 & 5.11 & 4.67 & 4.39 & 4.15 \\
\hline Leisure & 4.62 & 4.79 & 4.38 & 3.77 & 4.74 & 4.71 & 4.01 & 3.84 \\
\hline Friendships & 4.73 & 4.65 & 4.20 & 3.69 & 4.82 & 4.28 & 3.78 & 3.92 \\
\hline Family & 4.58 & 4.66 & 4.08 & 3.65 & 4.65 & 4.56 & 3.85 & 3.65 \\
\hline Community involvement & 4.54 & 4.74 & 3.78 & 3.61 & 4.69 & 4.62 & 3.58 & 3.78 \\
\hline Romantic relationships & 4.33 & 4.52 & 4.15 & 3.55 & 4.36 & 4.73 & 3.80 & 3.61 \\
\hline Number of respondents & 59 & 109 & 49 & 121 & 126 & 42 & 105 & 65 \\
\hline
\end{tabular}

Note: The data highlighted in italic presented statistically significant differences (ANOVA) at $p<0.05$ Source: Elaborated by the authors, based on the research data

\section{Urgent situation for Brazilian women}

$-1$ 
RAUSP

56,1

difference $(p<0.05)$ between women without children's and women with children's workfamily conflicts (4.65 and 4.56, respectively), there is no support for H3. Maybe, in the Brazilian context, "having children" acts as a decisive variable for making women develop stronger boundaries around family, as preconized by the asymmetrical domain permeability model (Ashforth et al., 2000; Pleck, 1977).

This result does not match Belkien's (2003) and Lucas' (2015) hypothesis on maternity as a variable that intensifies this conflict. If WNWC results from incongruence between desired and possible strategies toward work-nonwork integration or segmentation (Rothbard et al., 2005; Kreiner, 2006; Chen et al., 2009; Kreiner et al., 2009), it can be supposed though that among the women in the Brazilian sample (compared to men), the ones without children face a harder time to achieve congruence between desired and possible strategies. This can also derive from focusing hard on work and facing the invisible barriers to growing hierarchically such as the glass ceiling (Hymowitz \& Schelhardt, 1986) and labyrinth (Eagly \& Carli, 2007): it is so difficult to fight against something invisible, it takes so much energy, that little is left to worry about a strategy toward work-nonwork integration or segmentation.

For single men, higher conflicts are related to the education dimension. An interesting point to discuss is that, while women (in general) report not only more conflicts but also a bigger difference in dimensions related to collective aspects (community involvement, family, friendships and household management - Difference in Table 4), men (the single ones) are more affected only in a dimension that enhances a more individual factor, education.

Combining the variables sex, marital status and "having children or not," the differences are similar to the results already presented: compared to men with or without children, single women without children score higher on five out of 16 WNWC factors and married women, also without children, present higher scores on eight out of 16 WNWC factors. These results indicate the absence of children as a direct influence on women's conflict perception because women without children perceive more WNWC factors and do it more intensively. These results are also in line with Morgado's findings (2012) about the anguish single women feel because they dedicate themselves too much to work.

Closing the analyzes, H1 (For women, other nonwork dimensions than family are more affected in the WNWC) was supported and H2 (Women perceive less work-family conflict than men) and H3 (Women with children perceive more work-family conflict than women without children) rejected.

\section{Conclusions}

Traditionally, research and theories on WNWC use family as a synonym of nonwork. Recent publications, however, argue that focusing on work-family conflict may hide that women are having a hard time to fulfill the domestic and family demands expected from them (the gender role-expectations theory) but find it difficult to admit that they are unable to sufficiently protect these dimensions from work intrusions. Then, mainly, that focusing on work-family conflict may also hide women's and men's desire to enjoy other life dimensions besides work and family. These are important reasons to know more about other nonwork dimensions that may be invaded by work while comparing women's and men's perceptions: it is time to expand the analysis and the discussion concerning those other nonwork dimensions.

As research implications, the study highlights the need to include more nonwork aspects into career and management studies to influence organizational policies and practices and individual choices, by presenting data that show diversified interests beyond work, besides 
family. An important point is a variation among people (and between women and men) in the nonwork dimensions in which they spend time and how it also reflects different priorities in life beyond work. A similar scenario appears while investigating WNWC considering the seven nonwork dimensions other than family: these dimensions are affected differently by time or stress-based conflict from work.

Synthesizing, the comparisons between women and men support the first of the three tested hypotheses as, for women, three dimensions are more affected than family: household management, health and education. This result can help explain why there are contradictory findings when studies investigate only work-family conflict comparing women and men: women would still understand family care as their task, as expected according to the gender role-expectations theory and/or feel ashamed for not protecting this dimension enough, causing them not always to declare an intense work-family conflict. However, when given the opportunity, they (women) would show higher conflict levels toward other nonwork dimensions than family, as happened in this study.

Rejecting the other two hypotheses, women perceive more work-family conflict than men (H2) and women with children perceive less work-family conflict than women without children (H3). So, work and family demands seem more competitive for women, supporting the sexual division of labor, but having children seems to protect them from the perception of conflict: maybe the anguish is more intense when children are involved and it is too hard to admit the incapability of dealing with work intrusions. Another important result is that women seem to struggle more than men against social pressure coming from dimensions lived collectively (community involvement, family, friendships and household management) compared to more individual dimensions (health and education). After all, taking care of people is a female task and society charges them to fulfill this role.

This set of findings makes mainly women's well-being an urgent question to be addressed: women need to go out to work most of the time but remain the main responsible for family and household care, missing time and feeling stress more intensively when they desire to participate in other nonwork dimensions. They (women) express a more intense conflict from work considering the eight nonwork dimensions and extra anguish/shame may result when they become mothers.

As practical implications, knowing WNWC more and better will help organizations to improve lives by creating policies, practices and a cultural environment to preserve women's and men's nonwork times. It may also help people to choose better the places they want to work for, with the kind of social environment and policies that match their nonwork needs.

As social implications, the study reinforces that demands arise from new family arrangements, more and more couples in dual-career and an aging society: organizations need to prepare to have workers, men and women, who want to dedicate time to an individual or collective interests (other than family or children) to be healthy and productive or who need to take care of their elderly parents (not only their children), for example.

Methodological limitations include the non-probabilistic and convenience sample, which makes the results not generalizable and the self-reporting data collection. Self-reporting was chosen for a specific reason, as it permits capturing individual perceptions on the research phenomenon (WNWC). It evoked proactive measures to reduce method bias: the survey was anonymous, with communication on no wrong or right answers, randomization of questionnaire alternates and questions appropriate to the target sample.

Two other limitations result from the studied theoretical model (Keeney's model): there may be further nonwork dimensions such as spirituality, besides intersections between the eight studied dimensions (such as friendships and leisure) this study did not address.

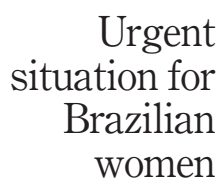

83 
RAUSP

56,1

For future studies, the suggestions are:

- qualitative methodology to deepen knowledge on how work has invaded the eight nonwork dimensions; it can be a useful tool for subsiding new organizational policies and practices to help workers in predicting and combating WNWC;

- to investigate if the age of the respondents (or its generations) and the age of their children affects the intensity of WNWC or the nonwork dimensions invaded may also help to develop those new policies and practices;

- to improve knowledge about the relation between WNWC and workers' well-being, especially in a society that will count on less ideal workers and will deal with greater diversity; and

- to investigate how organizations can encourage and value nonwork as a way to positively influence work satisfaction.

\section{Notes}

1. Likert scale, used with time allocation and WNWC variables, could be considered an interval scale as in Hair et al. (2009).

2. To estimate the universe, IBGE (2015) data were used, showing an occupied population of 98.1 million people in 2014; as well as MEC (2012) data, which appointed $7.9 \%$ of graduates in the country at the end of 2010 .

3. About 7,700 people received the email message with the survey; so, the response rate was $4.39 \%$.

4. The average dollar rate in May and June 2016 was US $\$ 1=\mathrm{R} \$ 3.48$.

\section{References}

Anderson, S. E., Coffey, B. S., \& Byerly, R. T. (2002). Formal organizational initiatives and informal workplace practices: Links to work-family conflict and job-related outcomes. Journal of Management, 28(6), 787-810.

Ashforth, B. E., Kreiner, G. E., \& Fugate, M. (2000). All in a day's work: Boundaries and micro role transitions. Academy of Management Review, 25(3), 472-491. Retrieved from: https://doi.org/ 10.5465/AMR.2000.3363315 doi: https://doi.org/10.5465/amr.2000.3363315.

Bailyn, L. (2006). Breaking the mold: Redesigning work for productive and satisfying lives, Cornell University Press.

Bedeian, A. G., Burke, B. G., \& Moffett, R. G. (1988). Outcomes of work-family conflict among married male and female professionals. Journal of Management, 14(3), 475-491. doi: https://doi.org/ 10.1177/014920638801400310.

Belkien, L. (2003). The opt-out revolution. New York Times Magazine, 42-47. Retrieved from: www. nytimes.com/2003/10/26/magazine/the-opt-out-revolution.html

Borelli, J. L., Nelson, S. K., River, L. M., Birken, S. A., \& Moss-Racusin, C. (2017). Gender differences in Work-Family guilt in parents of young children. Sex Roles, 76(5/6), 356-368. Retrieved from: https://doi.org/10.1007/s11199-016-0579-0 doi: https://doi.org/10.1007/s11199-016-0579-0.

Byron, K. (2005). A meta-analytic review of work-family conflict and its antecedents. Journal of Vocational Behavior, 67(2), 169-198. doi: https://doi.org/10.1016/j.jvb.2004.08.009.

Butler, J. (2016). Problemas de gênero: feminismo e subversão da identidade, 11th edition., Rio de Janeiro: Civilização Brasileira.

Cahusac, E., \& Kanji, S. (2014). Giving up: How gendered organizational cultures push mothers out. Gender, Work \& Organization, 21(1), 57-70. doi: https://doi.org/10.1111/gwao.12011. 
Calás, M. B., \& Smircich, L. (2007). Do ponto de vista da mulher: abordagens feministas em estudos organizacionais. Clegg, S. R., Hardy, C., \& Nord, W. R. (Eds), Handbook de estudos Organizacionais - Modelos de análise e novas questões em estudos organizacionais, São Paulo: Atlas. In

Carlson, D. S., \& Perrewé, P. L. (1999). The role of social support in the stressor-strain relationship: an examination of work-family conflict. Journal of Management, 25(4), 513-540. doi: https://doi.org/ 10.1177/014920639902500403.

Chen, Z., Powell, G. N., \& Greenhaus, J. H. (2009). Work-to-family conflict. positive spillover. and boundary management: a person-environment fit approach. Journal of Vocational Behavior, 74(1), 82-93. doi: https://doi.org/10.1016/j.jvb.2008.10.009.

Chies, P. V. (2010). Identidade de gênero e identidade profissional no campo de trabalho. Revista Estudos Feministas, 18(2), 507-528. doi: https://doi.org/10.1590/S0104-026X2010000200013.

Eagly, A. H., \& Carli, L. L. (2007). Women and the labyrinth of leadership. Harvard Business Review, 85(9), 63-71.

Eby, L. T., Casper, W. J., Lockwood, A., Bordeaux, C., \& Brinley, A. (2005). Work and family research in IO/OB: Content analysis and review of the literature (1980-2002. ). Journal of Vocational Behavior, 66(1), 124-197. doi: https://doi.org/10.1016/j.jvb.2003.11.003.

Goldin, C. (2013). A grand gender convergence: Its last chapter. American Economic Review, 104(4), 1091-1119. Retrieved from: https://doi.org/10.1257/aer.104.4.1091 doi: https://doi.org/10.1257/ aer.104.4.1091.

Goode, W. J. (1960). A theory of role strain. American Sociological Review, 25(4), 4. 483-496. doi: https:// doi.org/10.2307/2092933.

Greenhaus, J. H., \& Beutell, N. J. (1985). Sources of conflict between work and family roles. The Academy of Management Review, 10(1), 76-88. doi: https://doi.org/10.2307/258214.

Grzywacz, J. G., \& Butler, A. B. (2008). Work-family conflict. The SAGE Handbook of Organizational Behavior, 1, 451-468.

Gutek, B. A., Searle, S., \& Klepa, L. (1991). Rational versus gender role explanations for work-family conflict. Journal of Applied Psychology, 76(4), 560-568. doi: https://doi.org/10.1037/0021-9010.76.4.560.

Haar, J. M. (2013). Testing a new measure of work-life balance: a study of parent and non-parent employees from New Zealand. The International Journal of Human Resource Management, 24(17), 3305-3324. doi: https://doi.org/10.1080/09585192.2013.775175.

Hair, J. F., Black, W. C., Babin, B. J., Anderson, R. E., \& Tatham, R. L. (2009). Análise multivariada de dados, Bookman Editora.

Hirata, H., \& Kergoat, D. (2003). A divisão sexual do trabalho revisitada. In Maruani, M. \& Hirata, H. (Eds), As novas fronteiras da desigualdade: homens e mulheres no mercado de trabalho, pp. 111-123. São Paulo: Editora Senac. I

Hirschi, A., Herrmann, A., Nagy, N., \& Spurk, D. (2016). All in the name of work? Nonwork orientations as predictors of salary, career satisfaction, and life satisfaction. Journal of Vocational Behavior, $95,45-57$.

Hymowitz, C., \& Schelhardt, T. D. (1986). The Glass-Ceiling: Why women can't seem to break the invisible barrier that blocks them from top jobs. The Wall Street Journal, 57, D1D4-D1D5.

IBGE - Instituto Brasileiro de Geografia e Estatística (2010). Estatísticas de gênero. Retrieved from www.ibge.gov.br/apps/snig/v1/?loc $=0 \&$ cat $=-1 \cdot 1 \cdot 2 .-2 \cdot-3.128 .129 \&$ ind $=4728$

IBGE - Instituto Brasileiro de Geografia e Estatística (2013a). Pesquisa nacional por amostra de domicílios - síntese de indicadores. Retrieved from http://biblioteca.ibge.gov.br/visualizacao/ livros/liv94414.pdf

IBGE - Instituto Brasileiro de Geografia e Estatística (2013b). Síntese de indicadores sociais - uma análise das condições de vida. Retrieved from http://biblioteca.ibge.gov.br/visualizacao/livros/ liv66777.pdf 
RAUSP

56,1

IBGE - Instituto Brasileiro de Geografia e Estatística (2015a). Síntese de indicadores sociais: Uma análise das condições de vida da população brasileira. Disponível em: Retrieved from http:// biblioteca.ibge.gov.br/visualizacao/livros/liv95011.pdf

IBGE - Instituto Brasileiro de Geografia e Estatística (2015b). Folha de são paulo. Cresce diferença de jornada de trabalho entre homens e mulheres. Retrieved from www1.folha.uol.com.br/mercado/ 2017/02/1862048-cresce-diferenca-de-jornada-entre-homens-e-mulheres.shtml Access in: 20/11/ 2017.

IBGE - Instituto Brasileiro de Geografia e Estatística (2018). Uol economia. Mulheres ganham 77,5\% do salário dos homens no brasil, diz IBGE. Retrieved from https:/economia.uol.com.br/noticias/ redacao/2018/04/11/desigualdade-salarial-homem-mulher-ibge.htm?cmpid=copiaecola

Instituto Ethos (2018). Brasil é o segundo país com menos mulheres em cargos de alta gerência, revela pesquisa. Retrieved from https://www3.ethos.org.br/cedoc/brasil-e-o-segundo-pais-com-menosmulheres-em-cargos-de-alta-gerencia-revela-pesquisa-que-ouviu-executivos-da-america-latina/\#. W2zzoNJKjIU

Kahn, R. L., Wolfe, D. M., Quinn, R. P., Snoek, J. D. \& Rosenthal, R. A. (1964). Organizational stress: Studies in role conflict and ambiguity.

Keeney, J., Boyd, E. M., Sinha, R., Westring, A. F., \& Ryan, A. M. (2013). From “work-family" to "worklife": broadening our conceptualization and measurement. Journal of Vocational Behavior, 82(3), 221-237. doi: https://doi.org/10.1016/j.jvb.2013.01.005.

Kossek, E. E., \& Ozeki, C. (1998). Work-family conflict. policies. and the job-life satisfaction relationship: a review and directions for organizational behavior-human resources research. Journal of Applied Psychology, 83(2), 139-149. doi: https://doi.org/10.1037/0021-9010.83.2.139.

Kreiner, G. E. (2006). Consequences of work-home segmentation or integration: a person-environment fit perspective. Journal of Organizational Behavior, 27(4), 485-507. doi: https://doi.org/10.1002/ job.386.

Kreiner, G. E., Hollensbe, E. C., \& Sheep, M. L. (2009). Balancing borders and bridges: Negotiating the Work-Home interface via boundary work tactics. Academy of Management Journal, 52(4), 704-730. doi: https://doi.org/10.5465/amj.2009.43669916.

Lapierre, L. M., \& Allen, T. D. (2012). Control at work, control at home, and planning behavior: Implications for work-family conflict. Journal of Management, 38(5), 1500-1516. doi: https://doi. org/10.1177/0149206310385868.

Lucas, A. C. (2015). Justiça organizacional de gênero nas empresas: os sentidos atribuídos pelos profissionais de recursos humanos. Doctoral dissertation. Universidade de São Paulo.

Madalozzo, R., Martins, S. R., \& Shiratori, L. (2010). Participação no mercado de trabalho e no trabalho doméstico: homens e mulheres têm condições iguais. ? Revista Estudos Feministas, 18(2), 547-566. doi: https://doi.org/10.1590/S0104-026X2010000200015.

Marks, S. R. (1977). Multiple roles and role strain: Some notes on human energy. time and commitment. American Sociological Review, 42(6), 921-936. doi: https://doi.org/10.2307/2094577.

MEC - Ministério da Educação (2012). Número de brasileiros com graduação cresce 109,83\% em 10 anos. Retrieved from http://portal.mec.gov.br/component/content/article?id=17725:numero-debrasileiros-com-graduacao-cresce-10983-em-10-anos

Metz, I. (2011). Women leave work because of family responsibilities: Fact or fiction? Asia Pacific Journal of Human Resources, 49(3), 285-307. doi: https://doi.org/10.1177/1038411111413216.

Morgado, A. P. D. V. (2012). A mulher invisível: sentidos atribuídos à mulher e ao trabalho na gerência intermediária. Doctoral dissertation. Fundação Getúlio Vargas.

Nippert-Eng, C. (1996). Calendars and keys: the classification of "home" and "work. Sociological Forum, 11(3), 563-582. doi: https://doi.org/10.1007/BF02408393.

Oliveira, E. C., \& Casado, T. (2013). Balanço entre Vida Profissional. Familiar e Pessoal - Um Estudo Exploratório Quantitativo. 8th IAM - Iberoamerican Academy Conference. 
Oliveira, E. C., \& Casado, T. (2017). Validação do construto conflito Trabalho-Não trabalho no contexto brasileiro. Anais do Encontro Nacional da Associação Nacional de Pós-Graduação e Pesquisa em Administração.

Oliveira, L. B. D., Cavazotte, F. D. S. C. N., \& Paciello, R. R. (2013). Antecedentes e consequências dos conflitos entre trabalho e família. Revista de Administração Contemporânea, 17(4), 418-437. doi: https://doi.org/10.1590/S1415-65552013000400003.

Olson-Buchanan, J. B., \& Boswell, W. R. (2006). Blurring boundaries: Correlates of integration and segmentation between work and nonwork. Journal of Vocational Behavior, 68(3), 432-445. doi: https://doi.org/10.1016/j.jvb.2005.10.006.

Pleck, J. H. (1977). The Work-Family role system. Social Problems, 24(4), 417-427. Retrieved from: https://doi.org/10.1525/sp.1977.24.4.03a00040 doi: https://doi.org/10.1525/sp.1977.24.4.03a00040.

Rice, R. W., Frone, M. R., \& Mcfarlin, D. B. (1992). Work-nonwork conflict and the perceived quality of life. Journal of Organizational Behavior, 13(2), 155-168. doi: https://doi.org/10.1002/ job.4030130205.

Rocha-Coutinho, M. L. (2004). Novas opções, antigos dilemas: mulher, família, carreira e relacionamento no brasil. Temas Em Psicologia Da SBP, 12(1), 2-17. Retrieved from: https://oi.org/10.4013/ ctc. 2009.22 .02

Rothbard, N. P., Phillips, K. W., \& Dumas, T. L. (2005). Managing multiple roles: Work-family policies and individuals' desires for segmentation. Organization Science, 16(3), 243-258. doi: https://doi. org/10.1287/orsc.1050.0124.

Sampieri, R. H., Collado, C. F., \& Lucio, P. B. (2006). Metodologia de pesquisa, São Paulo: McGraw-Hill.

Shockley, K. M., Shen, W., DeNunzio, M. M., Arvan, M. L., Knudsen, E. A., \& Shockley, C. (2017). Disentangling the relationship between gender and work-family conflict: an integration of theoretical perspectives using Meta-Analytic methods. Journal of Applied Psychology, 102(12), 1601-1635. Retrieved from: https://doi.org/10.1037/ap10000246 doi: https://doi.org/10.1037/ ap10000246.

Sweeney, D. J., Williams, T. A., \& Anderson, D. R. (2013). Estatística aplicada à administração e economia, São Paulo: CENGAGE Learning.

Tabachnick, B. G., \& Fidell, L. S. (2007). Experimental design using ANOVA, Belmont: Thomson Higher Education.

Thompson, J. A., \& Bunderson, J. S. (2001). Work-nonwork conflict and the phenomenology of time: beyond the balance metaphor. Work and Occupations, 28(1), 17-39. doi: https://doi.org/10.1177/ 0730888401028001003.

Venturi, G., \& Godinho, T. (Eds) (2013). Mulheres brasileiras e gênero nos espaços público e privado: uma década de mudanças na opinião pública as cited Lucas. A. C. (2015). Justiça organizacional de gênero nas empresas: os sentidos atribuídos pelos profissionais de recursos humanos (Doctoral dissertation. Universidade de São Paulo).

\section{Corresponding author}

Érica Custódia de Oliveira can be contacted at: ericacol@yahoo.com.br

Associate Editor: Renata Schirrmeister

For instructions on how to order reprints of this article, please visit our website:

www.emeraldgrouppublishing.com/licensing/reprints.htm

Or contact us for further details: permissions@emeraldinsight.com 